\title{
Upaya Meningkatkan Hasil Belajar Pembahasan Mengungkapkan Berbagai Informasi Dengan Wawancara Melalui Role Playing Pada Siswa Kelas VIII SMP Muhammadiyah 1 Banda Aceh
}

\author{
Fatmawati \\ Guru SMP Muhammadiyah 1 Banda Aceh
}

\begin{abstract}
Abstrak
Penelitian ini bertujuan untuk meningkatkan hasil belajar siswa pada mata pelajaran Bahasa Indonesia dengan menggunakan metode Role Playing Metode penelitian yang digunakan adalah penelitian tindakan kelas (PTK) yang terdiri atas dua siklus, setiap siklus dilaksanakan 3 kali pertemuan dan pada pertemuan ketiga setiap siklus dilaksanakan pengukuran hasil belajar melalui tes . Yang menjadi subyek penelitian tindakan kelas ini adalah siswa kelas VIII SMP Muhammadiyah 1 Banda Aceh tahun pelajaran 2016/2017 sebanyak 31 siswa. Analisis data menggunakan teknik analisis diskriptif komparatif dengan membandingkan kondisi awal dengan hasil-hasil yang dicapai pada setiap siklus, dan analisis deskriptif kualitatif hasil observasi dengan membandingkan hasil observasi dan refleksi pada siklus I dan siklus 2. Dari hasil tes yang dilakukan setiap siklus terjadi peningkatan hasil belajar siswa secara signifikan, sehingga dapat diambil kesimpulan bahwa dengan menggunakan metode role playing dapat meningkatkan ketuntasan belajar siswa. Yaitu sebanyak $42 \%$ yaitu dari kondisi awal 35\% (hasil tes pra siklus) menjadi 77\% ( hasil tes siklus terakhir) terhadap siswa SMP Muhammadiyah 1 Banda Aceh. Dengan demikian penelitian ini telah dianggap berhasil dan dapat dijadikan referansi pagi guru lain guna meningkatkan prestasi belajar siswa.
\end{abstract}

\section{Kata Kunci : Metode, Role Playing, Bahasa Indonesia, Hasil Belajar}

\section{PENDAHULUAN}

Keberhasilan proses belajar mengajar sangat ditentukan oleh kemampuan guru dalam memerankan sebagai pemimpin, fasilitator, dinamisator dan sekaligus sebagai pembantu. Dalam kutipan Menteri Pendidikan No. 84/1993 antara lain disebutkan bahwa wewenang guru adalah memilih dan menentukan metode kerja untuk mencapai hasil pendidikan yang obtimal sesuai dengan kode etik guru.

Seorang guru harus mampu menetukan strategi atau cara (teknik) sehingga memiliki keyakinan dalam mendapatkan tujuan khusus dan tujuan umum dalam proses belajar. Dari hasil pemantauan dalam pelaksanaan kegiatan belajar mengajar banyak sekali permasalahan - permasalahan pada pembelajaran yang sering muncul antara lain kekurangan minat balajar, kurangnya minat belajar, siswa tidak dapat menguasai mata pelajaran apa yang kita harapkan tidak akan tercapai.

Berdasarkan hasil observasi awal yang penulis dapatkan pada siswa kelas VIII di SMP Muhammadiyah 1 Banda Aceh adalah kesulitan belajar didalam mempelajari pelajaran Bahasa Indonesia, kurangnya memahami bagaimana cara mengubah puisi kedalam bentuk prosa, dan bisa di simpulkan bahwa pembelajaran yang dilaksanakan pada siswa belum maksimal, sehingga hasil belajar tidak seperti yang diharapkan.

Dari pengamatan penulis siswa belum serius mengikuti pembelajaran dari guru, guru juga belum menggunakan cara-cara dan metode yang tepat, guru juga belum menggunakan strategi yang sesuai dengan indikator pembelajaran, pembelajaran seperti itu berakibat hasil belajarnya rendah, rendahnya hasil belajar terindikasi bahwa 
nilai yang diperoleh siswa juga masih rendah. Siswa yang mencapai ketuntasan belajar diperkirakan sekitar $40 \%$, sehubungan dengan hal tersebut diatas, penulis memperhatikan siswa yang tuntas belajar hanya lebih kurang $40 \%$ sedangkan $60 \%$ siswa belum tuntas belajar.

Faktor yang menjadi permasalahan adalah kurangnya kreatifitas guru dalam menggunakan metode dan strategi guna pencapaian indikator dan kompetensi dasar yang sesuai dengan yang diharapkan. pelaksanaan Penelitian Tindakan Kelas ini merupakan upaya penulis untuk meningkatkan hasil belajar siswa sehingga ketuntasan pada siswa dapat meningkat, peningkatan ketuntasan siswa diharapkan lebih baik yaitu dari awal ketuntasan belajar siswa $40 \%$

\section{KAJIAN TEORI}

\section{Hakikat Pembelajaran Bahasa Indonesia}

Belajar bahasa pada hakikatnya adalah belajar komunikasi. Oleh karena itu, pembelajaran bahasa diarahkan untuk meningkatkan kemampuan pebelajar dalam berkomunikasi, baik lisan maupun tulis (Depdikbud, 1995). Hal ini relevan dengan kurikulum 2004 bahwa kompetensi pebelajar bahasa diarahkan ke dalam empat subaspek, yaitu membaca, berbicara, menyimak, dan mendengarkan.

Sedangkan tujuan pembelajaran bahasa, menurut Basiran (1999) adalah keterampilan komunikasi dalam berbagai konteks komunikasi. Kemampuan yang dikembangkan adalah daya tangkap makna, peran, daya tafsir, menilai, dan mengekspresikan diri dengan berbahasa. Kesemuanya itu dikelompokkan menjadi kebahasaan, pemahaman, dan penggunaan. Sementara itu, dalam kurikulum 2004 untuk SMP, disebutkan bahwa tujuan pemelajaran Bahasa dan Sastra Indonesia secara umum meliputi:

- siswa menghargai dan membanggakan Bahasa Indonesia sebagai bahasa persatuan (nasional) dan bahasa negara

- siswa memahami Bahasa Indonesia dari segi bentuk, makna, dan fungsi,serta menggunakannya dengan tepat dan kreatif untuk bermacam-macam tujuan, keperluan, dan keadaan

- siswa memiliki kemampuan menggunakan Bahasa Indonesia untuk meningkatkan kemampuan intelektual, kematangan emosional,dan kematangan sosial

- siswa memiliki disiplin dalam berpikir dan berbahasa (berbicara dan menulis)

- siswa mampu menikmati dan memanfaatkan karya sastra untuk mengembangkan kepribadian, memperluas wawasan kehidupan, serta meningkatkan pengetahuan dan kemampuan berbahasa, dan

- siswa menghargai dan membanggakan sastra Indonesia sebagai khazanah budaya dan intelektual manusia Indonesia.

Untuk mencapai tujuan di atas, pembelajaran bahasa harus mengetahui prinsipprinsip belajar bahasa yang kemudian diwujudkan dalam kegiatan pembelajarannya, serta menjadikan aspek-aspek tersebut sebagai petunjuk dalam kegiatan pembelajarannya.

Prinsip-prinsip belajar bahasa dapat disarikan sebagai berikut, siswa akan belajar bahasa dengan baik bila:

- diperlakukan sebagai individu yang memiliki kebutuhan dan minat,

- diberi kesempatan berapstisipasi dalam penggunaan bahasa secara komunikatif dalam berbagai macam aktivitas

- bila ia secara sengaja memfokuskan pembelajarannya kepada bentuk, keterampilan, dan strategi untuk mendukung proses pemerolehan bahasa 
- ia disebarkan dalam data sosiokultural dan pengalaman langsung dengan budaya menjadi bagian dari bahasa sasaran,

- jika menyadari akan peran dan hakikat bahasa dan budaya,

- jika diberi umpan balik yang tepat menyangkut kemajuan mereka, dan

- jika diberi kesempatan untuk mengatur pembelajaran mereka sendiri (Aminuddin, 1994).

\section{Metode Role Playing Pada Pembelajaran Bahasa Indonesia Hakikat "Role Playing"}

Lee (1986: 147) menyatakan bahwa "Role Playing is an aspect of simulation. A whole situation is simulated in the classroom, and the participants adopt roles which belong to it". Dapat disimpulkan bahwa Role Playing merupakan bagian dari kegiatan simulasi. Situasi keseluruhan disimulasikan dalam kelas, dan para pembelajarnya memerankan peran dalam situasi keseluruhan tersebut. Menurut Harmer (2007: 352), dalam Role Playing , peran dan bagaimana peran dilaksanakan telah dipersiapkan dan ditentukan. Ladousse (1987: 5) menjelaskan arti dari Role Playing dengan memilah kata role play menjadi role dan play. Menurutnya, role berarti siswa memerankan bagian dalam situasi khusus. Sedangkan playing mengacu pada peran tersebut dilakukan dalam situasi tertentu dengan para siswa berusaha inventif dan dengan menyenangkan..

Menurut Gangel (1986), role playing adalah suatu metode mengajar merupakan tindakan yang dilakukan secara sadar dan diskusi tentang peran dalam kelompok. Pandangan senada dikemukakan oleh Blatner (2002), menurutnya role playing adalah sebuah metode untuk mengeksplorasi hal-hal yang menyangkut situasi sosial yang kompleks. Di dalam kelas, suatu masalah diperagakan secara singkat sehingga muridmurid bisa mengenali tokohnya. Salah satu struktur permainan menurut Gangel (1986) adalah sebagai berikut:

a) Persiapan

$\begin{array}{ll}\checkmark & \text { Tentukan masalah } \\ \checkmark & \text { Buat persiapan peran } \\ \checkmark & \text { Bangun suasana } \\ \checkmark & \text { Pilihlah tokohnya } \\ \checkmark & \text { Jelaskan dan berikan pemanasan } \\ \checkmark & \text { Pertimbangkan latihan } \\ \checkmark & \text { Memainkan } \\ \checkmark & \text { Menghentikan } \\ \checkmark & \text { Melibatkan penonton } \\ \checkmark & \text { Menganalisa diskusi } \\ \checkmark & \text { Mengevaluasi }\end{array}$

Semuanya berfokus pada pengalaman kelompok, bukan pada perilaku unilateral guru. Kelompok harus berbagi dalam menentukan masalah, membawakan situasi dalam role playing, mendiskusikan hasil, dan mengevaluasi seluruh pengalaman. Guru harus mengenalkan situasinya dengan jelas sehingga baik tokoh maupun penontonnya memahami masalah yang disampaikan.

\section{Fungsi Role Playing dalam Pembelajaran Bahasa Indonesia}

Lee (1986: 147) menjelaskan bahwa Role Playing bermanfaat untuk membantu membawa bahasa ke dalam kehidupan dan memberikan pengalaman nyata kepada pembelajar menggunakan bahasa sebagai alat komunikasi. Role Playing dalam kegiatan pembelajaran di kelas dapat dilaksanakan untuk meningkatkan pemahaman 
terhadap apa yang dipelajarinya, misalnya dalam pembelajaran yang susah dipahami oleh siswa dengan menggunakan metode role playing maka apa yang siswa pelajari akan lebih cepat di ingat siswa sudah mengalami/melakukan sendiri dengan bermain peran/role playing .

\section{Tahap Pelaksanaan Role Playing}

Shaftel \& Shaftel (dalam Amato, 2003: 223) merancang suatu tahapan yang terdiri atas sebelas tahapan dalam melaksanakan kegiatan Role Playing , yaitu: (1) memperkenalkan topik kegiatan, (2) mendorong ketertarikan pembelajar, (3) menyajikan kosakata baru, (4) membaca cerita yang secara jelas menuju pada suatu permasalahan, (5) menghentikan cerita pada saat klimaks, (6) mendiskusikan dilema yang ada, (7) memilih pembelajar memainkan peran, (8) mempersiapkan pembelajar yang lain untuk menyimak dan selanjutnya memberikan nasihat, (9) memerankan cerita yang tersisa, (10) mendiskusikan jalan keluar alternatif yang berhubungan dengan permasalahan, dan (11) memerankan kembali cerita menggunakan strategi baru bila diperlukan.

\section{Hasil Belajar Siswa}

Nawawi (1981:100) mengemukakan pengertian hasil adalah sebagai berikut: Keberhasilan murid dalam mempelajari materi pelajaran di sekolah yang dinyatakan dalam bentuk nilai atau skor dari hasil tes mengenai sejumlah pelajaran tertentu.

Pendapat lain dikemukakan oleh Sadly (1977:904), yang memberikan penjelasan tentang hasil belajar sebagai berikut, "Hasil yang dicapai oleh tenaga atau daya kerja seseorang dalam waktu tertentu", sedangkan Marimba (1978:143) mengatakan bahwa "hasil adalah kemampuan seseorang atau kelompok yang secara langsung dapat diukur".

Para ahli dibidang pendidikan dan psikologi mencoba mengidentifikasikan faktor-faktor yang mempengaruhi hasil belajar. Dengan diketahuinya faktor-faktor yang berpengaruh terhadap hasil belajar, para pelaksana maupun pelaku kegiatan belajar dapat memberi intervensi positif untuk meningkatkan hasil belajar yang akan diperoleh.

\section{Pembahasan mengungkap berbagai informasi dengan wawancara}

Wawancara adalah salah satu faktor penting dalam menggali informasi dari nara sumber, dalam hal ini rumah tangga sample. Dengan teknik wawancara yang baik dan benar diharapkan tujuan interview akan tercapai. Setiap enumerator harus mengetahui teknik wawancara yang efisien dan efektif.

\section{a) Wawancara yang Efisien dan Efektif}

- Persiapan diri dengan baik dengan cara memahami sepenuhnya cakupan isi kuesioner dan maksud dari setiap pertanyaan.

- Cermatilah setiap tanda yang menunjukkan catatan kaki ataupun keterangan agar tahu persis maknanya.

- Camkan dalam hati bahwa kita yang butuh data, bukan responden.

- Kembangkan dan pertahankan suasana komunikasi yang baik dengan responden dengan cara bersikap ramah, sopan, bersahaja, dan jangan tergesa-gesa.

- Untuk jenis-jenis pertanyaan yang (agak) sulit dijawab oleh responden, gunakan cara lain dalam bertanya tanpa mengubah makna dari pertanyaan yang tercantum dalam kuesioner. 
- Khusus untuk modul usahatani, pemahaman enumerator tentang komoditas yang diusahakan oleh responden sangat membantu, jaga konsistensi antara luas persil contoh dengan jawaban-jawaban responden mulai dari awal sampai akhir (dari pra-panen sampai pasca panen dan pengolahan). Apabila jawaban responden agak meragukan (misalnya penggunaan pupuk atau tenaga kerja pada persil contoh terlalu tinggi atau terlalu rendah), dikonfirmasikan lagi dengan hati- hati.

- Penggunaan gambar atau denah dalam menggali data yang berkenaan dengan lahan, usahatani, dan akan sangat membantu mempermudah wawancara.

- Pada waktu wawancara gunakan satuan-satuan setempat sesuai apa yang dimengerti dengan baik oleh responden. Jangan lupa catat konvensinya dengan satuan yang umum/standar.

- Selesai wawancara, lihat sekali lagi apakah semua pertanyaan yang relevan telah ditanyakan dan telah terisi jawabannya.

\section{METODOLOGI PENELITIAN}

Tempat dan Waktu penelitian

Penelitian tindakan kelas ini penulis laksanakan di kelas VIII SMP Muhammadiyah 1 Banda Aceh tahun ajaran 2016/2017. Penelitian ini penulis laksanakan selama dalam kurun waktu 2 bulan sejak Maret sampai April 2017 semester II tahun pembelajaran 2016/2017 Penelitian tersebut dilakukan pada waktu tersebut karena sesuai dengan program pembelajaran dan sesuai dengan kompetensi dasar yang diadakan sesuai dengan waktu tersebut.

\section{Subyek Penelitian}

Sebagai Subyek penelitian tindakan kelas ini adalah siswa-siswi kelas VIII SMP Muhammadiyah 1 Banda Aceh . Jumlah siswa sebanyak 31 orang yang terdiri dari 17 orang siswa laki-laki dan 14 orang siswa perempuan. Siswa tersebut berumur homogen, namun kecerdasan siswa sangat berbeda antara yang satu dengan yang lain.

\section{Teknik Pengumpulan data}

Tehnik pengumpulan data dalam penelitian ini menggunakan test dan observasi.

\section{Alat Pengumpul Data}

Alat pengumpulan data dalam penelitian ini yaitu menggunakan untuk butir soal test/instrumen, lembar observasi yang digunakan oleh pengamat untuk mengamati kegiatan siswa dan guru yang melaksanakan pembelajaran, lembar instrumen pembelajaran yang dilaksanakan oleh guru, pedoman wawancara untuk pihak yang terkait.

\section{Analisis Data}

Analisis data yang digunakan adalah analisi data deskriptif dengan membandingkan nilai test antar test. Analisis data yang berkaitan dengan pembelajaran hasil siswa dalam pembelajaran Bahasa Indonesia, dimana jawaban benar diberi skor 10 dan untuk jawaban salah diberi skor 0 , dengan menggunakan rumus:

Keterangan: $\mathrm{Na}$ : Nilai Akhir

$$
\mathrm{Na}=\frac{\mathrm{n}}{\mathrm{N}} \times 100 \%
$$

$\mathrm{n}$ : nilai yang diperoleh

$\mathrm{N}$ : nilai maksimal 
Hasil perhitungan dikonsultasikan dengan tabel kriteria deskriptif. Presentase yang dikelompokkan dalam 5 kategori yaitu sangat kurang, kurang, cukup, baik, sangat baik adalah sebagi berikut:

\section{Tabel Kriteria Deskriptif}

\begin{tabular}{|c|c|c|c|}
\hline No & Rentang Nilai & Katagori & Penafsiran \\
\hline $\mathbf{1}$ & $86-100$ & Sangat baik & Hasil belajar sangat baik \\
\hline $\mathbf{2}$ & $71-85$ & Baik & Hasil belajar baik \\
\hline $\mathbf{3}$ & $56-70$ & Cukup & Hasil belajar cukup \\
\hline $\mathbf{4}$ & $41-55$ & Kurang & Hasil belajar kurang \\
\hline $\mathbf{5}$ & $<40$ & Sangat kurang & Hasil belajar sangat kurang \\
\hline
\end{tabular}

(Depdiknas, 2002:4)

Tabel Kriteria Kentuntasan Minimal Mata Pelajaran Bahasa Indonesia

Kelas VIII SMP Muhammadiyah 1 Banda Aceh

\begin{tabular}{|c|c|c|}
\hline No & Rentang Nilai & Katagori \\
\hline $\mathbf{1}$ & $68-100$ & Tuntas \\
\hline $\mathbf{2}$ & $0-67$ & Belum tuntas \\
\hline
\end{tabular}

\section{HASIL PENELITIAN DAN PEMBAHASAN \\ Pelaksanaan Pra Siklus}

Pada pelaksanaan pembelajaran sebelum penelitian berjalan atau prasiklus pembelajaran pada mata pelajaran pendidikan Bahasa Indonesia masih rendah, rendahnya hasil belajar dapat berdampak pada rendahnya nilai yang dimiliki siswa sehingga berpengaruh pada pencapaian KKM.

Hasil tes siswa dapat diketahui bahwa siswa yang mencapai ketuntasan belajar diperkirakan sekitar $35 \%$, sedangkan $64 \%$ siswa lagi belum mencapai ketuntasan dalam belajar. Guru harus lebih kreatif lagi dalam mempersiapkan kematangan perencanaan pembelajaran. Berikut dapat dilihat hasil tes pra siklus :

Tabel Rekapan Hasil Belajar Siswa Pra Siklus

\begin{tabular}{|c|c|c|c|c|c|}
\hline No & $\begin{array}{c}\text { Hasil } \\
\text { (angka) }\end{array}$ & $\begin{array}{l}\text { Hasil } \\
\text { (huruf) }\end{array}$ & Arti Lambang & $\begin{array}{c}\text { Jumlah } \\
\text { Siswa }\end{array}$ & $\begin{array}{c}\text { Persentase } \\
(\%)\end{array}$ \\
\hline 1 & $86-100$ & A & Sangat baik & 0 & 0 \\
\hline 2 & $71-85$ & B & Baik & 0 & 0 \\
\hline 3 & $56-70$ & $\mathrm{C}$ & Cukup & 13 & 42 \\
\hline 4 & $41-55$ & $\mathrm{D}$ & Kurang & 18 & 58 \\
\hline 5 & $<40$ & $\mathrm{E}$ & Sangat kurang & 0 & 0 \\
\hline \multicolumn{4}{|c|}{ Jumlah } & 31 & $100 \%$ \\
\hline
\end{tabular}

Berdasarkan table diatas menunjukkan bahwa yang jumlah yang mendapat nilai sangat baik (86-100) adalah tidak ada (0\%), yang mendapat nilai baik (75-85) tidak ada (0\%), yang mendapat nilai cukup (56-70) berjumlah 13 orang (42\%), yang mendapat nilai kurang (41-55) berjumlah 18 orang (58\%) dan siswa yang mendapat nilai sangat kurang $(<40)$ tidak ada $(0 \%)$.

Tabel Ketuntasan Belajar Siswa Pra Siklus

\begin{tabular}{|c|l|c|c|}
\hline \multirow{2}{*}{ No } & \multirow{2}{*}{ Ketuntasan } & \multicolumn{2}{|c|}{ KKM 68 } \\
\cline { 3 - 4 } & Jumlah & Persentase (\%) \\
\hline 1 & Tuntas & 11 & 35 \\
\hline 2 & Tidak tuntas & 20 & 65 \\
\hline \multicolumn{2}{|c|}{ Jumlah } & $\mathbf{3 1}$ & $\mathbf{1 0 0}$ \\
\hline
\end{tabular}


Berdasarkan tabel diatas penulis dapat didiskripsikan bahwa persentase ketuntasan belajar siswa masih sangat jauh dari KKM minimal yang direncanakan yaitu siswa yang tuntas belajar berjumlah 11 orang atau $35 \%$ dari 31 jumlah siswa keseluruhan sedangkan yang tidak tuntas berjumlah 20 siswa atau $61 \%$

Tabel Rata-rata Hasil Tes Pra siklus

\begin{tabular}{|l|l|c|}
\hline No & \multicolumn{1}{|c|}{ Keterangan } & Nilai \\
\hline 1 & Nilai tertinggi & 75 \\
\hline 2 & Nilai Terendah & 50 \\
\hline 3 & Nilai Rata-rata & 61 \\
\hline
\end{tabular}

Berdasarkan table diatas menunjukkan bahwa nilai tertinggi adalah 75 , dan nilai terendah adalah 50, sedangkan nilai rata-rata siswa adalah 65 .

\section{Pelaksanaan Siklus I (Pertama)}

Pelaksanaan siklus I berlangsung dalam tiga kali pertemuan, yaitu tanggal 14 Maret 2017 (pertemuan pertama), 21 Maret 2017 (pertemuan kedua ) dan 28 Maret 2017 (pertemuan ke tiga. Pada pertemuan ke tiga dilakukan pengukuran hasil belajar siswa melalui test. Berikut tahapan siklus I:

\section{Perencanaan Tindakan}

Perencanaan yang penulis buat pada pertemuan 1 siklus I adalah menyiapkan perangkat pembelajaran untuk pertemuan 1 pada siklus I, yaitu sebagai berikut:

a. Menyusun silabus

b. Menbuat Rencana Pelaksanaan Pembelajaran (RPP)

c. Membuat Lembar Kerja Siswa (LKS)

d. Membuat instrmen soal

e. Membuat Lembar observasi

f. Memilih bahan ajar yang sesuai

\section{Pelaksanaan Tindakan}

Pada pelaksanaan kegiatan ini, penulis melakukannya sesuai dengan standar proses (PerMendiknas No 14 /2007), disamping itu penulis juga sudah mendesain atau merancang pembelajaran ini dengan menggunakan metode demonstrasi. Berikut langkah-langkah pembelajaran :

(1) Kegiatan Pendahuluan :

Pada kegiatan pendahuluan, penulis masuk kelas dengan,

a. Memberi salam

b. Membaca doa

c. Apersepsi

d. Mengabsen siswa

e. Mengelola kelas dengan baik

f. Memberi motivasi kepada siswa

g. Guru menulis indikator pembelajaran yang sesuai.

h. Membuat proses pembelajaran menyenangkan

(2) Kegiatan Inti :

a. Guru mengajukan pertanyaan kepada siswa tentang indikator dan Kompetensi Dasar pembelajaran sehingga mendapat jawaban dari siswa.

b. Guru melaksanakan skenario pembelajaran sesuai dengan metode Role Playing .

Berikut langkah-langkahnya :

$>$ Guru membagikan siswa dalam 5 kelompok, Kelompok siswa bersifat heterogen antara laki-laki dan perempuan

Guru Implementasikan metode Role Playing . 
Guru memberikan Lembar Kerja kelompok kepada siswa

Siswa mengerjakakan soal-soal yang diberikan oleh guru

Salah satu kelompok mengimplementasikan metode Role Playing dalam pembelajaran Bahasa Indonesia, kelompok lain memperhatikan dengan seksama

c. Guru memberikan penguatan kepada siswa

(3) Kegiatan Penutup

a. Memberikan kesimpulan-kesimpulan kepada siswa

b. Memberikan pesan moral

c. Memberkan rencana tindak lanjut/PR

\section{Observasi}

Pelaksanaaan observasi dilakukan oleh teman sejawat selaku pengamat terhadap pelaksanaan pembelajaran yang dilaksanakan oleh penulis dan terhadap aktifitas siswa didalam mengikuti proses pembelajaran. Pada pertemuan pertama menunjukkan bahwa pelaksanaan pembelajaran sudah sesuai dengan skenario atau rencana, akan tetapi ada beberapa hal yang perlu diperbaiki antara lain :

1. Guru belum maksimal membimbing siswa dalam membuat kesimpulan

2. Guru masih kurang dalam memberi motivasi bagi siswa

3. Guru melakukan penilaian belum maksimal

4. Pengelolaan waktu belum efektif

5. Dalam memberikan penguatan guru masih kurang.

6. Dalam menerapkan Role Playing dalam pembelajaran Bahasa Indonesia belum optimal sehingga kelas tidak dapat terkontrol.

Berikut hasil belajar siswa pada pertemuan pertama siklus 1 :

Adapun hasil belajar pada pertemuan ke 2 yang telah penulis lakukan dengan melaksanakan tes/pengukuran pada akhir pembelajaran kedua memperoleh hasil sebagai berikut :

Tabel Rekapan Hasil Belajar Siswa Siklus I

\begin{tabular}{|c|c|c|c|c|c|}
\hline No & $\begin{array}{c}\text { Hasil } \\
\text { (angka) }\end{array}$ & $\begin{array}{c}\text { Hasil } \\
\text { (huruf) }\end{array}$ & Arti Lambang & $\begin{array}{c}\text { Jumlah } \\
\text { Siswa }\end{array}$ & $\begin{array}{c}\text { Persentase } \\
(\%)\end{array}$ \\
\hline 1 & $86-100$ & $\mathrm{~A}$ & Sangat baik & 0 & 0 \\
\hline 2 & $71-85$ & $\mathrm{~B}$ & Baik & 6 & 19 \\
\hline 3 & $56-70$ & $\mathrm{C}$ & Cukup & 19 & 61 \\
\hline 4 & $41-55$ & $\mathrm{D}$ & Kurang & 6 & 19 \\
\hline 5 & $<40$ & $\mathrm{E}$ & Sangat kurang & 0 & 0 \\
\hline \multicolumn{4}{|c|}{ Jumlah } & 31 & $100 \%$ \\
\hline
\end{tabular}

Berdasarkan table diatas menunjukkan bahwa yang jumlah yang mendapat nilai sangat baik (86-100) adalah tidak ada (0\%), yang mendapat nilai baik (75-85) berjumlah 6orang (19\%), yang mendapat nilai cukup (56-70) berjumlah 19 orang (61\%), yang mendapat nilai kurang (41-55) berjumlah 6 orang (19\%) dan siswa yang mendapat nilai sangat kurang $(<40)$ tidak ada $(0 \%)$.

Tabel Ketuntasan Belajar Siswa Siklus I

\begin{tabular}{|c|l|c|c|}
\hline \multirow{2}{*}{ No } & \multirow{2}{*}{ Ketuntasan } & \multicolumn{2}{|c|}{ KKM $\mathbf{6 8}$} \\
\cline { 3 - 4 } & & Jumlah & Persentase (\%) \\
\hline 1 & Tuntas & 15 & 48 \\
\hline 2 & Tidak tuntas & 16 & 52 \\
\hline \multicolumn{2}{|c|}{ Jumlah } & $\mathbf{3 1}$ & $\mathbf{1 0 0}$ \\
\hline
\end{tabular}


Berdasarkan tabel diatas dapat dijelaskan bahwa persentase ketuntasan belajar siswa sudah mulai meningkat yaitu siswa yang tuntas belajar menjadi 15 siswa ( 48\%) dari 31 jumlah siswa keseluruhan sedangkan yang tidak tuntas berjumlah 16 siswa $(52 \%)$

Tabel Rata-rata Hasil Tes siklus I

\begin{tabular}{|l|l|c|}
\hline No & \multicolumn{1}{|c|}{ Keterangan } & Nilai \\
\hline 1 & Nilai tertinggi & 80 \\
\hline 2 & Nilai Terendah & 50 \\
\hline 3 & Nilai Rata-rata & 65 \\
\hline
\end{tabular}

Berdasarkan table diatas menunjukkan bahwa nilai tertinggi adalah 80 , dan

nilai terendah adalah 50, sedangkan nilai rata-rata siswa adalah 65 .

\section{Refleksi}

Setelah siklus I selesai dilaksanakan beserta penilaian terhadap hasil belajar siswa, aktivitas siswa dan kemampuan guru dalam melaksanakan PBM, guru peneliti bersama dengan guru kolaborasi membuat pertemuan untuk membahas tentang tindakan yang harnus diperbaiki serta tindakan yang harus dipertahankan pada proses belajar mengajar di siklus II . Pada dasarnya pembelajaran yang dilakukan oleh guru peneliti sudah berada diangka cukup dan masih harus ditingkatkan lagi :

1. Memotivasi siswa agar aktif belajar

2. Membimbing siswa mengerjakan tugas

3. Membimbing siswa dalam membuat kesimpulan

4. Memberi penguatan di akhir pembelajaran.

5. Memaksimalkan penggunaan metode pembelajaran / penguasaan metode pembelajaran harus ditingkatkan lagi.

Pada siklus ke II terjadi peningkatan yang sangat signifikan, jumlah siswa yang nilainya di katagori sangat kurang/kurang tidak ada lagi. Pada katagori cukup menjadi $58 \%$, pada katagori baik menjadi 19\% dan pada katagori sangat baik menjadi $25 \%$.

Grafik Perkembangan Ketuntasan belajar siswa tiap Siklus

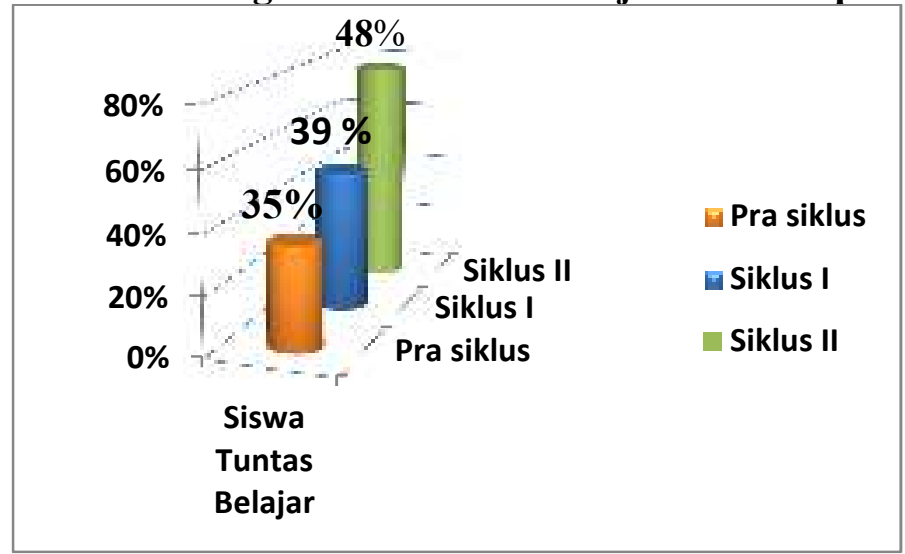

Dari grafik diatas dapat di jelaskan bahwa hasil belajar siswa yang dapat mencapai KKM (tuntas belajar) sebelum dilakukan penelitian tindakan kelas ini atau Pra siklus adalah sebanyak $35 \%$, dan setelah dilakukan tindakan pada siklus I tingkat ketuntasan belajar menjadi 48\%, pada siklus II meningkat menjadi $77 \%$ ini berarti terjadi peningkatan ketuntasan belajar siswa sebanyak $42 \%$ dari kondisi awal 35\% menjadi $77 \%$.

Dengan demikian berdasarkan kedua grafik diatas dapat disimpulkan dengan penggunaan metode role playing bisa menjadi salah satu acuan guru untuk meningkatkan hasil belajar siswa pada mata pelajaran Bahasa Indonesia . Khususnya dalam materi atau pembahasan mengungkap berbagai informasi dengan wawancara 


\section{Kesimpulan}

Berdasarkan hasil penelitian maka dapat disimpulkan bahwa Metode Role Playing adalah suatu cara penguasaan bahan-bahan pelajaran melalui pengembangan imajinasi dan penghayatan siswa sehingga dalam penggunaan metode ini akan lebih cepat ditangkap oleh siswa. Kelebihan metode role playing adalah meningkatnya keaktifan peserta didik selama proses pembelajaran yang disebabkan unsur dalam role playing seperti peserta didik sebagai pelaku pembelajaran, unsur permainan sekaligus hiburan. Dengan penggunaan metode role playing bisa menjadi salah satu acuan guru untuk meningkatkan hasil belajar siswa pada mata pelajaran Bahasa Indonesia khususnya dalam pembahasan mengungkap berbagai informasi dengan wawancara. Dengan menggunakan metode role playing dapat meningkatkan ketuntasan belajar siswa sebanyak $42 \%$ yaitu dari kondisi awal 35\% (hasil tes pra siklus) menjadi $77 \%$ (hasil tes siklus terakhir).

\section{DAFTAR PUSTAKA}

Aminudin. 1994. Pengantar Memahami Unsur-unsur dalam Karya Sastra. Malang: FPBS IKIP

Amato, P. R., \& Previti, D. (2003). People's reasons for ... dating couples. Behavior

A.D. Marimba. (1978). Psikologi Perkembangan. Jakarta: Aksara Baru

Basiran, Mokh. (1999). Apakah yang Tuntut GBPP Bahasa Indonesia Kurikulum 1994?. Yogyakarta:Depdikbud

Depdikbud. 1995. Kamus Besar Bahasa Indonesia. Jakarta : Balai Pustaka.

Lee (1986: 147) menambahkan bahwa "role-playing is an aspect of simulation.

Harmer, Jeremy. (2007). The Practice of English Language Teaching, Fourth. Edition. Pearson Longman: Harlow.Modification, 24, 2, 223-240.

Nawawi. (1981). Metode-Metode Mengajar. Jakarta : Pustaka Pelajar. 